IZA DP No. 7789

Part-time Work, Wages and Productivity: Evidence from Belgian Matched Panel Data

Andrea Garnero

Stephan Kampelmann

François Rycx

November 2013 


\title{
Part-time Work, Wages and Productivity: Evidence from Belgian Matched Panel Data
}

\author{
Andrea Garnero \\ ENS, Paris School of Economics \\ and SBS-EM (CEB, DULBEA) \\ Stephan Kampelmann \\ Université Libre de Bruxelles, SBS-EM (CEB, DULBEA) \\ François Rycx \\ Université Libre de Bruxelles, SBS-EM (CEB, DULBEA) \\ and IZA
}

Discussion Paper No. 7789

November 2013

\author{
IZA \\ P.O. Box 7240 \\ 53072 Bonn \\ Germany \\ Phone: +49-228-3894-0 \\ Fax: +49-228-3894-180 \\ E-mail: iza@iza.org
}

\begin{abstract}
Any opinions expressed here are those of the author(s) and not those of IZA. Research published in this series may include views on policy, but the institute itself takes no institutional policy positions. The IZA research network is committed to the IZA Guiding Principles of Research Integrity.

The Institute for the Study of Labor (IZA) in Bonn is a local and virtual international research center and a place of communication between science, politics and business. IZA is an independent nonprofit organization supported by Deutsche Post Foundation. The center is associated with the University of Bonn and offers a stimulating research environment through its international network, workshops and conferences, data service, project support, research visits and doctoral program. IZA engages in (i) original and internationally competitive research in all fields of labor economics, (ii) development of policy concepts, and (iii) dissemination of research results and concepts to the interested public.
\end{abstract}

IZA Discussion Papers often represent preliminary work and are circulated to encourage discussion. Citation of such a paper should account for its provisional character. A revised version may be available directly from the author. 
IZA Discussion Paper No. 7789

November 2013

\section{ABSTRACT \\ Part-time Work, Wages and Productivity: Evidence from Belgian Matched Panel Data}

The authors use matched employer-employee panel data on Belgian private-sector firms to estimate the relationship between wage/productivity differentials and the firm's labor composition in terms of part-time and sex. Findings suggest that the groups of women and part-timers generate employer rents, but also that the origin of these rents differs (relatively lower wages for women, relatively higher productivity for part-timers). Interactions between gender and part-time suggest that the positive productivity effect is driven by male part-timers working more than 25 hours, whereas the share of female part-timers is associated with wage penalties. The authors conclude that men and women differ with respect to motives for reducing working hours and the types of part-time jobs available to them: women often have to accommodate domestic constraints by downgrading to more flexible jobs, whereas male part-time work is frequently related to training and collectively negotiated hours reductions that do not affect hourly pay.

JEL Classification: J22, J24, J31

Keywords: $\quad$ wages, productivity, part-time employment, gender, matched panel data, GMM

Corresponding author:

François Rycx

Université Libre de Bruxelles

Avenue F.D. Roosevelt, 50 - CP-140

1050 Brussels

Belgium

E-mail: frycx@ulb.ac.be

\footnotetext{
* We would like to thank Statistics Belgium for giving access to the data. We are also grateful to Rosemary Batt, Peter Berg, Gerhard Bosch, Jean Charest, Lonnie Golden, Sile O'Dorchai and participants at the EALE, SOLE and ILRR International Working Time conferences for helpful comments and discussions. Funding for this research was provided by the Belgian Federal Government - SPP Politique scientifique, programme "Société et Avenir", Employment, wage discrimination and poverty, research contract TA/00/046/EDIPO. All remaining errors are the authors' responsibility.
} 


\section{INTRODUCTION}

Over the past three decades, part-time jobs have become a prominent feature of many structural labour market changes in Europe and North America, and different scholars have identified part-time employment as one of the main factors underpinning processes of job flexibilization (Branine 1999; Edwards and Robinson 2000). Given that this type of employment majoritarily concerns women, it also raises issues linked to gender equality and the way in which contemporary societies organize the reconciliation of job market participation with non-market activities (Connolly and Gregory 2010).

In this paper we provide quantitative results for the relationship between the intra-firm composition of labour in terms of working hours and gender, on the one hand, and the firm's average hourly wage and average productivity on the other hand. The paper contributes to the literature on part-time work by estimating the effect of male and female part-time employment on productivity, wages, and productivity-wage gaps for the case of Belgian private-sector firms; we are notably able to measure potential economic rents.

To do so, we use detailed longitudinal matched employer-employee data over the period 1999-2010. Our data offer several advantages. First, the panel provides accurate information on average productivity and wages within firms (i.e. on the average added value per hour and the mean hourly wage) and enables us to consider a wide range of worker and firm characteristics (such as sex, education, age, occupation, type of contract, firm size, capital endowment, and sector). Second, we are able to tackle various potential biases that are not always accounted for in the empirical literature on part-time work such as firm-level fixed unobserved heterogeneity and endogeneity issues (possible unobserved time-varying factors remain a limitation of our approach). Finally, our study takes the heterogeneity of part-time employment into account and examines the distinction between 'short' and 'long' part-time (Hirsch 2005; Russo and Hassink 2008). Indeed, the repercussions of part-time arrangements on wages and productivity are likely to differ substantially according to whether the individual is absent during much of the work week (short part-time) or almost working fulltime (long part-time). 


\section{REVIEW OF THE LITERATURE}

\subsection{Theoretical background}

In this section we present three partly overlapping explanations for differences in hourly pay and productivity between part- and full-time workers and discuss their potential gender dimension.

\subsubsection{Cost structure of employment}

A first cluster of theories concerns the cost structure of firms. The existence of fixed costs including administrative costs of maintaining records for each employee, recruitment and firing costs, and fringe benefits that are independent of working hours - generally implies that total labour costs do not increase proportionally with working hours (Montgomery 1988). As a result, part-time workers are relatively more costly and may therefore receive lower wages. It can also be argued that part-time workers may give rise to coordination costs (Lewis 2003): while part-time can be easily managed in a Taylorist organisation in which workers can be substituted for each other, organisations that rely on task-specific skills may experience that part-time jobs create communication gaps or jeopardize output continuity (Bonamy and May 1997). The cost advantages and disadvantages associated with managing a part-time workforce have been recorded in a qualitative analysis of the nursing profession in the UK by Edwards and Robinson (2004). Questionnaire respondents identified disadvantages such as communication problems, an increase in administrative costs, overhead expenditures associated with training and difficulties regarding service continuity.

Female employment might also affect the cost structure if employers associate female jobs with relatively higher costs, for instance due to faster turn-over or more absenteeism due to the fact that women are more likely to be constrained by domestic or care duties and have more fractured career patterns due to maternity leaves.

\subsubsection{Labour productivity}

The second cluster of theories is concerned with differences in labour productivity. Most theories concern productivity gaps between full- and part-time jobs; it is rare to find arguments that associate productivity differences directly with sex. A well-known argument 
against part-time work is that daily start-up costs imply that productivity picks up only slowly during the working day. As a result, the worker's productivity during the last hour of work exceeds average productivity (Barzel 1973). However, other authors point to the tiredness associated with long working hours and argue that part-time workers could outperform their fatigued full-time colleagues (Brewster and al. 1994). In addition, part-time jobs might allow individuals to make better use of the circadian rhythm and reduce the amount of stress, potentially leading to higher performance (Pierce and Newstrom 1983; Baltes et al. 1999).

A challenge associated with part-time work is that managers might not always adjust expectations correctly when employees move from full to part-time, thus influencing the effectiveness of flexible work policies (Stanworth 1999). For instance, working reduced hours often entails to deal in a shorter time with what effectively remains a full-time workload (Edwards and Robinson 2000; Lewis 2001, 2003), a phenomena that could lead to a gap between productivity and wages of part-time workers.

Productivity gains from part-time can be realised by dividing work hours over a larger pool of employees; by extending opening hours without increasing payroll costs; or by exploiting firm-specific capital more intensively. In short, part-time often means that employers can react more flexibly to market changes and needs. Shepard et al. (1996) indeed argue that flexible working hours and alternatives to the traditional full-time work schedule might increase productivity and wages; for instance, part-time wage premia have been observed in sectors facing seasonal or fluctuating demand that cannot be managed through the carrying of inventories. In this context, employers may pay higher wages to part-time workers in order to staff highly productive peak periods. Results in Hagemann et al. (1994), using a survey of 3,000 employees in five German companies from different industries show that: i) standard part-time (i.e. employees working fewer hours per day) increases motivation and reduces absenteeism; ii) cyclical part-time enables to manage peaks and troughs in demand more efficiently (e.g. in industries such as tourism and banking); and iii) shift-based part-time might extend operating hours, leading to a more intense use of capital. Productivity-enhancing effects of part-time have also been found in a study using the National Organizations Survey of US firms by Perry-Smith and Blum (2000) and in estimates based on the employeremployee cross-sectional dataset of Dutch pharmacies by Nelen et al. (2011).

Policies in favour of part-time work are often justified by the idea that reduced hours enable individuals with multiple roles (especially women) to reconcile commodified and private work, thereby leading to higher productivity. While the direct effect of part-time on productivity is rarely measured, there is some evidence that part-time reduces stress (a 
phenomenon arguably related to multiple duties at work and home). For instance, the study of Branine (2003) based on data obtained from a questionnaire and interviews of hospital staff in the UK, France, and Denmark finds that part-time work is usually associated with low absenteeism and less stress. Moreover, the study by Edwards and Robinson (2000) uses qualitative analysis of the metropolitan police service in the UK to document that part-time work helps to retain experienced staff who would otherwise exit the labour force (especially women) and to increase job satisfaction and commitment.

Finally, an important productivity effect of part-time relates to human capital. Indeed, many authors hypothesize a negative relationship between working hours and involvement in training (Jepsen, 2001). One of the underlying mechanisms is that part-timers might arguably be less committed to career goals and that domestic responsibilities and career interruptions could crowd out personal investments in training, but employers might also be less willing to invest in the training of part-time workers. Empirical research tends to back the claim of lower human capital accumulation among part-timers. Felstead et al. (2000) show that workers moving from full- to part-time employment are likely to experience a stagnation of skills. Walby and Olsen (2003) find that women working part-time are the least likely to improve their skills. Branine (2003) also presents evidence that part-time is associated with low employment commitment and relatively lower skills. Edwards and Robinson (2000) cite the marginalization of part-time workers in terms of training among the disadvantages of these work arrangements. On average, the part-time nurses interviewed by Edwards and Robinson (2004) declared to be less satisfied with training opportunities and promotions than their full-time colleagues.

\subsubsection{Institutional factors}

The final set of theories argues that pay differentials are often related to the institutional embeddedness of male and female part-time employment. Several studies have shown that part-timers are characterised by a lower level of union membership (Riley 1997) and are

assumed to have lower bargaining power (Skåtun 1998). Negotiated overtime premia are a case in point: in most sectors unions have successfully lobbied for overtime premia for fulltime employees exceeding contractually fixed working hours, while extra hours of part-time workers generally do not give rise to any overtime premium. Collective bargaining is likely to affect men and women differently given that unionization is typically stronger in predominantly male occupations/sectors. As a consequence, decentralisation of bargaining 
increases inter-sectoral pay differentials and gender/part-time wage penalties since women and part-timers are clustered in the same low-paying sectors (Teuling and Hartog, 1998).

Another factor is related to fiscal policies. Countries like Belgium, France, Germany and the UK promote part-time by subsidizing it through reduced social security contributions or tax relief which could lead to lower wage costs for employers. Also the composition of income and payroll taxes may influence the wage difference between full-time and part-time workers (Koskela and Schöb 1999). However, payroll taxation is also found to decrease the wage rate with the number of hours worked.

Pay penalties for part-time workers and women have also been associated with intra-firm decision-making structures that are often biased towards (male) full-time employees. The latter group enjoys privileged access to formal and informal information and power, which in turn leads to different career patterns and gender pay gaps (Grimshaw and Rubery 2001). In the broader perspective, female part-time work cannot be dissociated from the societal division of work based on stereotypical patterns: women still accomplish relatively more domestic (and almost always unpaid and low-status) work, while male roles involve more often commodified work and the pursuit of a career as 'bread-winner'.

Finally, the legislative context could influence the relationship between productivity and wages of women and part-time workers. In addition to fiscal policy, anti-discrimination laws, minimum wage legislation and institutionalised rights to request flexible working (in the UK introduced in 2003) may have a positive impact on the relative remuneration of both parttimers and women.

In light of the different theories reviewed in this section, the task of empirical research in this area should be to disentangle the relative incidence of each of the different factors so as to explain any gaps between part-timer's productivity and wages. Unfortunately, the literature has so far not even firmly established whether such gaps actually exist.

\subsection{Empirical evidence on productivity-wage gaps}

The reason why the empirical literature still struggles to determine the precise magnitude of pay gaps is twofold. On the one hand, the studies on productivity effects of male and female part-time we mentioned above do not compare productivity patterns with wage differentials. On the other hand, studies decomposing the wage gap between part-time and full-time workers do not include independent productivity measures. Instead, they rely on proxy 
variables such as education, occupation, sector of activity, experience, etc. which capture productivity differentials only imperfectly.

Bardasi and Gornick (2008), for instance, use micro-data for 1995 from the Luxembourg Income Study and find a significant part-time pay penalty for women in a crosscountry comparison of Canada, Germany, Italy, Sweden, the UK and the US. But with the exception of Sweden, they conclude that much of these gaps should be attributed to different forms of segregation because worker and job controls substantially reduce the part-time pay penalty. Analogous results for the UK labour market can be found in Manning and Petrongolo (2008) who use pooled data from the Labour Force Survey from 2001 to 2003 to show that differences in the types of jobs and occupational segregation are the main factors associated with the hourly part-time pay penalty inflicted on British women. Hardoy and Schone (2006) use pooled data for 1997 and 1998 from the Norwegian Level of Living Surveys and record no hourly wage differences between female part-time and full-time and no evidence of systematic selection bias after controlling for observed characteristics. Rodgers (2004) develops a cross-sectional analysis using the 2001 wave from the Household, Income and Labour Dynamics in Australia Survey and does not find significant hourly part-time pay gaps for Australian workers once selection into types of employment and worker and job characteristics are controlled for. Also Booth and Wood (2008), using panel data of the first four waves of the same survey (2001-2004), do not detect any part-time penalty in Australia. In fact, they observe the opposite: once unobserved individual heterogeneity is taken into account part-time women and men appear to be paid a premium.

Hirsch (2005) uses level and longitudinal estimates of wages from the US Current Population Survey (1995-2002) and also ascribes the largest share of the hourly part-time penalty to differences in worker and job characteristics; once full controls are included in the model, he finds that the part-time pay gap is very modest at the beginning of individual careers. However, the part-time wage penalty tends to increase over time, a phenomenon that might reflect that part-timers accumulate lower levels of experience and human capital. Similar patterns are found by Russo and Hassink (2008), who use the pooled waves from 1999 and 2001 of the Working Conditions Survey for the Dutch labour market, and the study of career biographies of women from the UK by Connolly and Gregory (2010). On a societial scale, potentially negative effects of part-time on productivity are also likely to reinforce the traditional division of labour within households and create a negative feedback effect on the remuneration of part-time workers and women (Blau, 1984). 
A very appealing way to avoid the problematic reliance on imperfect productivity proxies in these studies has been presented by Hellerstein et al (1999) and refined by Hellerstein and Neumark (2004) and others. In a nutshell, the authors use matched employeremployee data in order to simultaneously measure the contribution of women (and other groups of employees) to both added value and the firm's average wage (Section 4 presents the approach in more detail). Hellerstein et al. conclude that US women appear to be relatively less productive than their male colleagues, but also that this productivity difference is significantly smaller than the pay gap between men and women. In other words, women as a group appear to generate economic rents for their employers. Our study builds on Hellerstein et al.'s pioneering work but combines the estimation of the relative productivity and wages of women with the issue of part-time work, in particular the potential interaction between working time and sex. Indeed, no study we are aware of uses accurate information on both wages and productivity in order to investigate whether part-time work generates economic rents and, a fortiori, whether part-time rents differ for men and women.

\subsection{The case of Belgium}

The development of part-time work in Belgium occurred earlier and affects a greater proportion of the labour force than in most OECD countries (OECD 2012). ${ }^{1}$ Some authors have argued that the principle cause for this trend is not the feminization of the Belgian labour force per se, but rather economic crises and job shortages that have led employers and policy makers to propose part-time arrangements to women. Anecdotal evidence for this proposition is the discriminatory character of early part-time arrangements introduced in the 1980, such as the case of the Belgian firm Bekaert-Cockerill: in 1982, to face the problems encountered on its site in Fontaine-l'Evêque, the firm imposed mandatory part time on all female employees who were not household heads (Plasman 2007).

In 2011, the Belgian part-time rate as a percentage of total employment was 18.8 percent, a figure that is 2.2 percentage points higher than the OECD average. Belgium is not exceptional as regards the overrepresentation of women in part-time jobs. Indeed, in 2011 the proportion of women working less than full hours was 25.4 percentage points higher than the corresponding male rate of only 7 percent. As for segregation into occupations and sectors of activities, part-time workers in Belgium are overrepresented in elementary, service and craft

\footnotetext{
${ }^{1}$ In this paragraph we refer to OECD statistics based on the part-time threshold of 30 weekly working hours (see below).
} 
occupations as well as in the manufacturing sector, hotels and restaurants, and the transport and telecommunications sector (Meulders and O’Dorchai 2009).

The regulation of part-time work in Belgium heavily relies on collective bargaining agreements at the national and sectoral level. These agreements cover all Belgian workers (i.e. their coverage rate is $100 \%)$. Unlike their counterparts in the United States, Belgian part-time workers are covered by unemployment insurance independently of the amount of hours worked. Benefits and other kinds of non-wage advantages are typically defined on a pro rata basis. Like in most countries, the progressivity of income tax encourages the reduction of working time in order to fall within lower tax brackets.

Some of the Belgian collective bargaining agreements incorporate explicit antidiscrimination rules. Meulders and O’Dorchai (2009) argue that Belgian labour law is more favourable to waged workers than the 1993 European Union Directive on working time allowing firms to opt out on certain elements of the Directive, such as the maximum number of weekly working hours. Unsurprisingly, in June 2008 Belgium voted against the application of this opt-out clause in the Council of Ministers of the EU. Belgium's antidiscrimination policies compare favourably with EU Member States and the country is considered a 'good European pupil' (Institute for the equality of women and men, 2010; p. 71).

Similar to related work on other countries cited above, empirical studies on Belgium suggest that pay penalties associated with part-time work and sex are correlated with individual and firm characteristics. Jepsen (2001) and Jepsen et al. (2005) use data on the 1990s from the Household Panel Survey and the Structure of Earnings Survey, respectively, and conclude that the pay difference between part- and full-time women is accounted for by observable characteristics. O’Dorchai et al. (2007) find that male part-timers are paid 24 percent less per hour than male fulltimers, but only 28 percent of this difference is left unexplained by observables in their Oaxaca-Blinder decomposition. Jepsen (2001) finds that only 13.7 percent of the full-time gender pay gap remains after introducing observable characteristics. The above-mentioned shortcoming of Oaxaca-Blinder-type decompositions of course also applies to extant studies on Belgium: in the absence of an independent productivity measure, observable characteristics only ‘explain' observed part-time wage gaps if they are correlated with labour productivity.

The productivity effects of part time are likely to depend on the motives that lead individuals to reduce working hours; if men and women reduce working hours for different reasons, we might observe a gender bias in the productivity effects of part-time. Anxo et al. (2002), for instance, have shown that the presence of children is among the chief determinants 
of women's working hours. A representative picture of part-time motives for Belgian men and women can be found in the European Union Statistics on Income and Living Conditions (EUSILC), Eurostat's EU-wide panel survey, which among many other job-related variables includes the item "reason for working less than 30 hours per week". Figure 1 shows the results for the Belgian sample for the period 2008-2010. Comparing the answers of 436 men and 2,453 women working less than 30 hours reveals a clear gender bias: the most frequent reason for female part-time is "Household work, looking after children or other persons" (29.9 percent of female responses), followed by "Do not want to work more" (28.3 percent). The most frequent responses for men are "Want to work more hours but cannot find a job(s) or work(s) of more hours“ (25 percent) and "Number of hours considered as a full-time job” (24.5 percent). Moreover, 7.1 percent of men state to work part-time due to training or education activities, against only 1.4 percent of women. In Section 5 we show how these response patterns can be linked to our empirical findings.

$\{\{$ Place Figure 1 about here $\}\}$

\section{DATA AND DESCRIPTIVE STATISTICS}

\subsection{Data}

Our empirical analysis is based on a combination of two large data sets spanning the period 1999-2010. The first is the Structure of Earnings Survey (SES). It covers all firms operating in Belgium that employ at least 10 workers and with economic activities within sections $\mathrm{C}$ to K of the NACE nomenclature (Rev. 1). The survey contains a wealth of information, provided by the management of firms, both on the characteristics of the latter (e.g. sector of activity, number of workers, level of collective wage bargaining) and on the individuals working there (e.g. age, education, tenure, gross earnings, paid hours, sex, occupation, etc). ${ }^{2}$ The SES provides no financial information. Therefore, it has been merged with a firm-level survey, the

\footnotetext{
${ }^{2}$ The SES is a stratified sample. The stratification criteria refer respectively to the region (NUTS-groups), the principal economic activity (NACE-groups) and the size of the firm. Sampling percentages of firms are respectively equal to 10, 50 and 100 percent when the number of workers is lower than 50, between 50 and 99 , and above 100. Within a firm, sampling percentages of employees also depend on size. Sampling percentages of employees reach respectively 100, 50, 25, 14.3 and 10 percent when the number of workers is lower than 20, between 20 and 50, between 50 and 99, between 100 and 199, and between 200 and 299. Firms employing 300 workers or more have to report information for an absolute number of employees. To guarantee that firms report information on a representative sample of their workers, they are asked to follow a specific procedure. For more details see Demunter (2000).
} 
Structure of Business Survey (SBS). The SBS provides information on financial variables such as firm-level added value and gross operating surplus per hour. The coverage of the SBS differs from the SES in that it does not include the whole financial sector (NACE J) but only Other Financial Intermediation (NACE 652) and Activities Auxiliary to Financial Intermediation (NACE 67). The data collection and merger of the SES and SBS datasets has been carried out by Statistics Belgium using firms’ social security numbers.

Two filters have been applied to the original data set. Firstly, we deleted firms that are publicly controlled and/or operating in predominantly public sectors from our sample. The rationale of this filter derives from standard productivity theory and the requirement that prices have to be economically meaningful. All regressions are therefore applied to privately controlled firms only. ${ }^{3}$ Secondly, in order to ascertain that firm averages are based on a sufficient number of observations we filtered out firms that provided information on less than 10 employees. $^{4}$

Our final sample (used in the difference Generalized Method of Moments (GMM) specification, see below) consists of an unbalanced panel of 1,430 firms and 128,006 individuals, yielding 5,171 firm-year-observations during the 12 year period (1999-2010). It is representative of all medium-sized and large firms employing at least 10 employees within sections $\mathrm{C}$ to $\mathrm{K}$ of the NACE Rev. 1 nomenclature, with the exception of large parts of the financial sector (NACE J) and almost the entire electricity, gas, and water supply industry (NACE E).

Our earnings measure corresponds to total gross wages, including premia for overtime, weekend or night work, performance bonuses, commissions, and other premia. Work hours represent total effective remunerated hours in the reference period (including paid overtime hours). The firm's added value per hour is measured at factor costs and based on the total number of hours effectively worked by the firm's employees. All variables in the SES-SBS are provided by the firm's management and therefore more precise compared to self-reported employee or household surveys.

\footnotetext{
${ }^{3}$ More precisely, we eliminate firms for which public financial control exceeds $50 \%$. This exclusion reduces the sample size by less than $2 \%$.

${ }^{4}$ This selection is unlikely to affect our results as it leads only to a small drop in sample size.
} 


\subsection{Descriptive statistics}

It is standard practice to define part-time with reference to the national benchmark of full-time working hours (ILO Part-Time Work Convention No. 175 from 1994; Bardasi and Gornick 2008; Manning and Petrongolo 2008). In Belgium, national collective agreements fix maximum working time at 38 hours per week and 8 hours per day. These thresholds are renegotiated by social partners in most industries and/or firms so that actual statutory maximum working hours are often closer to 35 hours per week and 7 hours per day (Meulders and O’Dorchai 2009). Working hours exceeding these thresholds are typically treated as overtime. In our data, the 35-hour mark clearly stands out as threshold separating the bulk of 'normal' full-time employments from the rest of the workforce (see vertical lines in panels a (women) and b (men) of Figure 2) and we therefore define part-time work as involving less than 35 hours per week (cf. Rodgers 2004; Booth and Wood 2008).

\section{$\{\{$ Please place Figure 2 about here $\}\}$}

Past research has highlighted considerable heterogeneity among part-time workers (Hirsch 2005; Russo and Hassink 2008). For instance, the repercussions of part-time arrangements are likely to differ according to whether the individual is absent during much of the work week (e.g. an employee with peripheral tasks coming in only one or two days per week) or whether she is almost working full-time (e.g. an employee who works similarly to her full-time colleagues during the entire week but leaves the office on Friday noon). Panel a of Figure 2 is a quantitative illustration of the heterogeneity of female part-time work: the distribution has two local peaks around 20 and 30 hours per week. In the absence of an obvious threshold to distinguish 'short' from 'long' part-time, we used three different limits for short part-time: 20, 25 and 30 hours (see Section 4.3). We therefore distinguish between three groups: workers with up to 20/25/30 hours (short part-time); between 20/25/30 and 35 hours (long part-time); and 35 or more working hours per week (full-time). ${ }^{5}$

\section{$\{\{$ Please place Table1 about here $\}\}$}

\footnotetext{
${ }^{5}$ The proportion of workers receiving payments for overtime hours is relatively limited in our sample. Moreover, the mean number of overtime hours among these workers is generally not very large. Yet, robustness tests have been performed (not reported in the paper due to space constraints but available upon request) to ensure that results reported below are insensitive to misclassifications of workers into long part-time or full-time categories due to the inclusion of overtime hours.
} 
Applying these definitions to the Belgian SES wage data yields an average wage gap between full-time men and women of 11 percent during the 2000s (see Table 1). The gender wage gap among workers with short and long part-time was 7 and 20 percent, respectively. We also observe wage penalties linked to working time: women with long part-time jobs earn 9 percent less than female fulltimers, whereas the penalty for short part-timers is 26 percent. The corresponding wage penalties among men are 12 and 16 percent, respectively.

\section{$\{\{$ Please place Table1 about here $\}\}$}

Table 2 sets out the means of selected variables both at the firm and individual level. At the firm level, the average share of fulltimers is 76.8 percent, the shares of short and long part-time are 5.5 and 17.6 percent, respectively. ${ }^{6}$ Moreover, 22 percent of hours are worked by women; 52.1 percent by workers younger than 40 years; and 3.8 percent by people on fixed-term contracts.

At the individual level, we observe a positive relationship between working time and the hourly added value of the firm in which the individual is employed. The group of full-time workers contains a higher share of individuals below 40 years (53.3) compared to short and long part-time; the distribution of educational credentials is positively related with the length of the working week, with women being better educated than men in our sample (34 percent have reached ISCED levels 5, 6 or 7 compared to only 22 percent of men). The incidence of fixed-term work contracts is similar among full-time and long part-time workers (around 4 percent), but twice as high among short part-timers.

In several occupations full-time jobs clearly predominate, namely managers, professionals and technicians. By contrast, the proportion of part-time among elementary occupations is considerably higher. The distribution of working time is highly gendered, so that the information in Table 2 can be complemented with figures on the occupational distribution and working regimes by sex (see Appendix A). For instance, the share of clerical occupations among male fulltimers is 10.6 percent and decreases to 4.4 among part-timers; female clerks, however, represent a higher share of full-time jobs (40.1 percent), but also remain the biggest group among long and short part-time jobs. Crafts and machine operators are more evenly distributed with respect to working time, but these occupations are much more frequent among male workers. The opposite holds for service and elementary

\footnotetext{
${ }^{6}$ The share of group $x$ in firm $y$ is computed as the ratio of the hours worked by group $x$ divided by the total amount of hours worked within firm $y$.
} 
occupations: the share of these groups is higher among women and represents respectively 9.1 and 23.5 percent of all female short part-time hours.

As to the distribution of working time regimes across sectors of activity, fulltimers are overrepresented in the construction sector, whereas long part-time jobs are overrepresented in manufacturing. Short part-time is overrepresented in hotels and restaurants, services (real estate, renting and business activities) and transport, storage and communication. The distribution across sectors and working regimes differs among men and women (Appendix A). Men are more concentrated in manufacturing and construction, two sectors that also provide the bulk of male part-time jobs; we find higher shares of women in wholesale and retail, transport, storage and communication as well as real estate, renting and business activities. The latter concentrates 22.2 percent of all short part-time hours worked by women (compared to only 5.8 percent for men).

\section{ESTIMATION STRATEGY AND RESULTS}

\subsection{Model specification}

Our model is based on the separate estimation of an added-value function and a wage equation at the firm level. The added-value function yields estimates for the average marginal product of each category of workers (part-time workers, women, etc), while the wage equation estimates the respective impact of each group on the average wage paid by the firm. Estimating both equations with the same set of explanatory variables allows comparing the parameters regarding the (average) marginal product and the (average) wage. This technique was pioneered by Hellerstein et al. (1999; 2004) and refined by Aubert and Crépon (2003) and van Ours and Stoeldraijer (2011). It is now standard in the literature regarding the productivity and wage effects of labour heterogeneity (Cataldi et al. 2012; Göbel and Zwick 2012).

The firm-level average productivity and wage equations in our baseline specification (Model 1) are:

$$
\begin{aligned}
& \log (\text { Value Added } / \text { Hours })_{i, t}=\alpha+\beta A_{i, t}+\delta B_{i, t}+\lambda X_{i, t}+\varepsilon_{i, t} \\
& \log (\text { Total Wages } / \text { Hours })_{i, t}=\alpha^{*}+\beta^{*} A_{i, t}+\delta^{*} B_{i, t}+\lambda^{*} X_{i, t}+\varepsilon_{i, t}^{*}
\end{aligned}
$$


The dependent variable in equation (1) is firm i's hourly added value, obtained by dividing the total added value by the firm $i$ in period $t$ by the total number of working hours (taking into account paid overtime hours). The dependent variable in equation (2) is firm i's average hourly gross wage (including premia for overtime, weekend or night work, performance bonuses, commissions, and other premia), i.e. the firm's total wage bill divided by total hours. The independent variables are shares in total work hours: for instance, parttime shares are measured in terms of the proportion of hours worked by part-time workers over the total amount of hours worked within the firm.

The main variables of interest are the shares of hours worked by part-time and female workers $\left(A_{i, t}\right.$ and $\left.B_{i, t}\right)$. The shares of full-time and male workers are thus our reference categories. Model 1 serves as the baseline specification and is extended in Sections 4.3 and 4.4: the former introduces the distinction between short and long part-time work (Model 2); the latter also includes the distinction between short and long part-time but in addition allows for the impact of these regimes to differ among men and women (Model 3). ${ }^{7}$

All models include the vector $X_{i, t}$ containing a set of observable characteristics of the firm and its labour force. More precisely, it contains the size of the firm and its square; respectively two and seven covariates for the educational and occupational composition of the workforce; the share of workers younger than 40 years; the fraction of workers with a fixedterm employment contract, the firm's capital stock ${ }^{8}$, eight dummy variables for economic sectors and eleven year dummies.

Estimating equations (1) and (2) allows gauging the effect of the shares of part-time and female workers on firm productivity and wages, but it does not allow testing directly whether the difference between added-value and wage coefficients is statistically significant for a given group of workers. A straightforward test for the significance of productivity-wage gaps has been proposed by van Ours and Stoeldraijer (2011). We apply a similar approach and estimate a model in which the difference between firm i's hourly value added and hourly wage is regressed on the same set of explanatory variables as in equations (1) and (2). This produces coefficients for the different groups measuring directly the size and significance of their respective productivity-wage gaps.

\footnotetext{
${ }^{7}$ We also tested for nonlinearities by including the main explanatory variables in level and squared. Estimates (available on request) reject the significance of non-linear coefficients and support our results concerning the linear effects presented in this section.

${ }^{8}$ It is estimated through the "perpetual inventory method" (see OECD, 2009), which rests on the simple idea that the capital stock results from investment flows (available in our data) after correction for retirement and efficiency loss. Following standard practice, we assume a 5 percent annual rate of depreciation of capital.
} 
Equations (1) and (2), as well as the productivity-wage gap, can be estimated using different methods, for instance pooled Ordinary Least Squares (OLS) or a fixed-effect model. However, pooled OLS estimators of productivity models have been criticized for their potential "heterogeneity bias" (Aubert and Crépon 2003: 116) due to the fact that firm productivity (and mean wages) depend to a large extent on firm-specific, time-invariant characteristics that are not measured in micro-level surveys. As a consequence, these estimators might be biased since unobserved firm characteristics may simultaneously affect the firm's added value (or wage) and the composition of its workforce. This is referred to as a problem of spurious correlation and could be caused by factors such as an advantageous location of the firm, firm-specific assets like the ownership of a patent or other firm idiosyncrasies.

While estimating firm-level fixed-effects enables us to attenuate the problem of unobserved firm characteristics, the fixed-effect estimator does not address the potential endogeneity of the explanatory variables. The composition of a firm's workforce is likely to be endogenous for several reasons: firstly, workers might choose or accept to work either part-time or full-time according to their degree of job commitment; secondly, any shock in productivity levels (or in wages) might generate correlated changes in the firm's workforce and in labour productivity (or wages) that are not due to changes in the firm's workforce composition per se: for instance, in periods of cyclical downturn firms might reduce workers' time schedules in order to save on labour costs. In order to tackle both firm-fixed unobserved heterogeneity and potential endogeneity, we estimate Model 1 using a GMM-DIFF estimator. This approach is standard in the literature on the productivity and wage effects of labour heterogeneity (Black and Lynch 2001; Daerden et al. 2006; Van Ours and Stoeldraijer 2011; Göbel and Zwick 2012). It boils down to instrumenting the first-differenced shares of parttime and female workers with their lagged levels (we used first and second lags). The implicit assumption is that changes in productivity and wages in one period, although possibly correlated with contemporaneous variations in the shares of part-time and female workers, are unrelated with lagged levels of the latter. Moreover, changes in the shares of part-time and female workers are assumed to be reasonably correlated to their past levels.

In order to assess the soundness of this approach we performed a range of statistical tests. The first test measures whether the correlation between the instrumental variables and the endogenous variables is low, in which case we would have 'weak' instruments. We used the Kleibergen-Paap rk Wald F statistic to test whether the excluded instruments are relevant. Under the null hypothesis the instruments are weak, i.e. they are not sufficiently correlated 
with the endogenous variables. Van Ours and Stoeldraijer (2011) suggest rejecting this hypothesis if the F-statistic is at least 10. The second test is the Kleibergen-Paap rk LM statistic, whose null hypothesis is that the equation is underidentified. The third test concerns the validity of additional instruments and uses the Hansen (1982) test of overidentifying restrictions. Under the null hypothesis the instruments are valid, i.e. uncorrelated with the error term. A fourth indicator tests whether the shares of part-time and/or female workers are indeed endogenous so that an IV approach is warranted. Under the null hypothesis the explanatory variables can actually be treated as exogenous.

\subsection{Model 1 - Shares of part-time and female workers}

Table 3 shows GMM-DIFF estimates of (baseline) Model 1. The figures in column (3) are estimated with (the logarithm of) the difference between the firm's hourly added value and average wage as dependent variable, columns (1) and (2) are obtained with (the logarithm of) the firm's added value per hour and its average hourly wage as dependent variable, respectively. All models have a good fit and pass the Chi-square test. All equations also pass the statistical tests for underidentification, weak identification and overidentification. In addition, we find that the null hypothesis that the shares of part-time and female workers are exogenous can be rejected both in the value-added and productivity-wage gap equations. In the wage regression, the p-value associated to the endogeneity test is equal to 0.12 . Results for the wage equation based on first-differences without instrumenting (available on request) confirm the negative wage effect for women (the significant coefficient is -0.20) and suggest a significant but small negative wage effect for part-timers (-0.03).

$\{\{$ Please place Table 3 about here $\}$ \}

Estimates for the control variables reflect other findings in the literature. For instance, relative to the reference category (i.e. the share of workers that are 40 years or older), a higher share of younger workers is negatively related with the firm's hourly wage: relative to the group of elderly workers, an increase of one percentage point in the share of young workers decreases hourly wages by around 0.14 percent (i.e. $0.14 * 0.01=0.0014=0.14$ percent), whereas young workers have no significant impact on added value. The combined result of these two effects is shown in the third column, i.e. the coefficients explaining the gap between added-value and hourly wage. The significant coefficient of 0.19 indicates that a relative 
increase in the share of younger workers generates on average a positive rent for the firm, corroborating similar results for Belgium found by Cataldi et al. (2012). Estimates regarding the firm's occupational mix also mirror earlier findings that occupations are associated with significant rents (Gottschalk 1978; Kampelmann and Rycx, 2012): while the firm's occupational composition has a significant impact on the average wage, no similar pattern emerges in the added-value equation - in fact, the productivity coefficients for occupations do not display any significant difference relative to the respective reference groups (service occupations).

Regarding the firm's share of part-time workers, three important results emerge from Table 3. First, we observe that the length of the working week matters for firm productivity: relative to the reference category of fulltimers, a one percentage point change in the share of part-timers is associated with a 0.08 percent change in the firm's productivity. Second, the firm's composition in terms of different working time regimes seems to be unrelated to the average hourly wage: the part-time wage coefficient is statistically insignificant. This corroborates findings by Jepsen (2001) and Jepsen et al. (2005) that part-time work in Belgium is not associated with significant pay penalties once we control for variables like sex, education, occupation and sectors of activity. Third, our results regarding the gap between added value and average wages suggest that an increase in the group of part-time workers generates positive rents for the average employer (the significant coefficient equals 0.09).

Table 3 further shows that women as a group are also associated with economic rents (the significant coefficient in the gap equation is 0.12). But the origin of these rents is different compared to the effect of part-time work: they do not stem from higher productivity relative to the reference group (men), but from a significantly negative impact on the firm's hourly wage. This is in line with estimations by Jepsen (2001), who finds a negative price effect for women in the Belgian labour market, but differs from those of Vandenberghe (2011) who rejects the hypothesis of gender wage discrimination. ${ }^{9}$

\subsection{Model 2 - Distinction between long and short part-time}

Our second model allows for the part-time effect to differ between 'short' and 'long' parttime. In the absence of any obvious upper threshold for short part-time, Table 4 shows results

\footnotetext{
${ }^{9}$ Yet, it should be noted that Vandenberghe (2011) focuses on mean labour costs per employee (rather than on average gross hourly wages), has no information individual working hours and includes a much smaller set of covariates (heterogeneity in education, age, working time and employment contracts is notably not accounted for).
} 
for three alternative thresholds: 20 (Model 2.1), 25 (Model 2.2) and 30 weekly working hours (Model 2.3). The added-value and gap equations in all three models pass all four statistical tests, suggesting that our instrumental variables approach is both warranted and valid. In contrast, results suggest that the shares of part-time and female workers are not endogenous in the wage regressions. Yet, estimates obtained for the wage equations with the first-difference estimator (available on request) are not substantially different from those reported in Table 4.

\section{$\{\{$ Please place Table 4 about here $\}\}$}

The results for Model 2 corroborate the conclusion of Model 1 regarding the share of female workers: the combination of a significantly negative wage effect and the absence of a productivity difference with respect to the share of male workers suggests that female workers as a group are associated with significant economic rents. The corresponding gap coefficient hardly varies between Models 2.1, 2.2 and 2.3.

Model 2 confirms the above result that part-time workers appear to be more productive relative to fulltimers and that after controlling for observed and firm fixed unobserved characteristics part-time is not associated with differences in pay. However, the distinction between short and long part-time allows pinpointing this effect: all three variations of Model 2 converge in suggesting that the positive impact on productivity is only associated with long part-time - no productivity effect is observed for short part-time. Models 2.1 and 2.2 further indicate that long part-time is associated with significant economic rents. In Model 2.3 these rents are also positive but not significant ( $\mathrm{p}$-value $=0.15)$, a result that suggests that the threshold of 30 hours is probably too high to capture rent differences between full-time and long part-time.

\subsection{Model 3 - Interactions between sex and part-time shares}

Model 3 further refines the analysis by allowing for the effect of short and long part-time to differ between men and women. While adding interaction variables generally comes at the cost of decreasing the precision with which each effect is measured (Göbel and Zwick, 2012), results for Model 3 corroborate Model 2: the positive productivity effect of part-time continues to be associated with long rather than short part-time; and both long part-time and the group of women are associated with significant economic rents (see Table 5). But Model 3 also yields additional insights. Firstly, the positive productivity effect of long part-time 
appears only for the subgroup of male long part-time workers but not for women. Secondly, we observe contrasting wage profiles for women and men. ${ }^{10}$ While for men a shorter week is associated with a (slight and not always significant) increase of the firm's hourly wage, for women we observe wage penalties that are inversely related to the length of the working week: in Model 3.1 (based on a threshold for short part-time of 20 weekly working hours), the negative wage coefficients for female full-time, long part-time and short part-time are -0.11, 0.18 and -0.25 , respectively. Women thus accumulate the negative wage effects associated with their sex and with working fewer hours. Finally, the profiles for the gap equation suggest that female full-timers and the group of long part-time workers are associated with employer rents. These rents have different origins according to sex: for male long part-timers the origin lies in their relatively higher productivity, for female long part-timers ${ }^{11}$ and full-timers they can be attributed to the relatively lower pay of these groups. For one of the three variants of Model 3 we also observe significant negative rents (from the employer perspective) associated with male short part-time work, but this result is somewhat unstable.

\section{$\{\{$ Please place Table 5 about here $\}\}$}

\section{DISCUSSION AND CONCLUSION}

The empirical studies reviewed in Section 2.2 typically 'explain' a significant portion of both the part-time and the gender pay gap using a range of productivity proxies, in general in the framework of Oaxaca-Blinder decompositions. Our approach overcomes two serious limitations of this literature: first, instead of analysing part-time and gender issues separately, we are able to provide estimates of potential interactions; and second, we not only control for a range of individual and firm characteristics typically found in wage gap decompositions (such as education, age, occupation, sector of activity and contract type), but also use an independent productivity measure at the firm level and distiguish between short and long parttime work arrangements. Moreover, our GMM-DIFF approach enables to control for firm

\footnotetext{
${ }^{10}$ The endogeneity test again indicates that the null hypothesis of exogeneity cannot be rejected for the wage regression. However, results based on the first-difference estimator (available on request) are in line with those shown in Table 5.

${ }^{11}$ The coefficient associated to female long part-time in the gap equation with the 30 hours threshold is only significant at the 12 percent probability level.
} 
time-invariant unobserved heterogeneity and for the endogeneity of proportions of part-time and female workers.

Our results mark three incremental steps. Model 1 provides separate estimates for the effects of the intra-firm shares of part-time workers and women. Findings suggest that both characteristics are related to employer rents, but also that these rents are generated through different mechanisms. In the case of part time, the gap between added value and wages per hour is related to a higher productivity relative to the group of fulltimers. By contrast, the rents from female workers appear to be driven by the relatively low pay of this group.

Model 2 introduces the distinction between short and long part time and enables us to pinpoint the productivity of part-time work: results indicate that it is long and not short parttime that is linked to higher added value per hour. This finding is in line with theories that emphasize a positive effect of part-time on labour productivity (Section 2.1.3), but we are not aware of an explicit theory that accounts for the hump-shaped productivity profile we document in this paper: starting with low productivity and low working hours, labour productivity first increases with the length of the work week but then decreases once the fulltime threshold (35 hours) is reached. As a consequence, it appears that above around 25 hours per week certain negative aspects of part-time (start-up costs, coordination problems, lower accumulation of human capital, etc) are more than off-set by positive effects (management of fluctuations, longer opening hours, etc). The idea that the observed pattern is driven by a combination of overlapping factors is in line with the fact that our results are insensitive to the exact threshold defining short and long part-time.

Model 3 allows for the effect of short and long part-time to differ among men and women. Despite the higher number of interaction variables in the model, results tend to corroborate the finding of economic rents associated with the shares of both women and long part-timers. In fact, we find a positive gap between the added-value and wage effect for female full-timers and both male and female long part-timers, but the origin of these gaps differ: for the group of male workers in long part-time jobs it is related to increases in firm productivity without increasing hourly wages, while changes in the share of female full-timers and long part-timers are associated with lower wages without decreasing productivity.

Our findings underline the importance of including a gender dimension in the analysis of part-time. Model 3 provides evidence that women's lower pay is tightly related to their involvement in part-time work: the shorter the working week, the higher is the wage penalty inflicted on women. But this does not mean that there is no gender effect because male part- 
timers appear not to suffer pay losses. A relevant analytical question is therefore how working less-than-normal working hours yields different outcomes for men and women.

We argue that part of the answer is provided by evidence that a) men and women typically do not have the same motives for working part-time; and b) that the opportunity structure in terms of availability and types of part-time jobs differs among men and women.

Regarding the motives for reduced hours, Section 2.3 shows that male workers are more likely to use part-time to engage in training (and many men want to work longer hours), whereas women put forth domestic duties as the main rationale for working reduced hours (and many women declare not to want to increase hours). In this context, human capital theory predicts that male part-timers are more productive and therefore paid higher wages.

But individual motives can only be a partial explanation given that they necessarily interact with the opportunity structure in which men and women operate. Male part-time is concentrated in certain capital-intensive and unionized sectors (manufacturing, construction) and occupations (crafts, machine operators), and EU-SILC data suggest that relatively more men consider their part-time jobs to be full-time jobs. In Belgium and other European countries with similar gender differences in the employment structure, it is therefore plausible that numerous part-time jobs in predominantly male occupations and industries are likely to be the result of collectively negotiated reductions in working hours. These arrangements are often accompanied with corresponding changes in workplace design but not with reductions in hourly pay rates.

This contrasts with female part-time whose predominance in service occupations and sectors means that hours reductions are less likely to be the result of collective bargaining. Moreover, as Connolly and Gregory (2008) show for the UK, women switching from full- to part-time employment often do so at the expense of occupational downgrading and the loss of firm-specific skills, especially if the employer provides few part-time positions so that women are forced to switch firms in order to reduce hours. Female part-time is therefore more likely to be the result of individual reductions of working hours that are associated with significantly lower wages (without being less productive).

Although our findings suggest that beyond around 25 weekly working hours both male and female part-time work gives rise to employer rents, the welfare implications for men and women are quite different: compared to full-timers, male part-timers do not reap the full benefits of productivity increases but their hourly pay rates do not suffer from this. In contrast, while female part-time does not affect productivity, it is more likely to generate precarity due to the combination of fewer working hours and lower hourly wages. 
A challenge for future research in this area is to analyse in more detail the interplay between gender-related differences in individual motives and opportunity structures, for instance by combining data on individual biographies (such as the surveys used by Connolly and Gregory 2008) with firm-level data on productivity and labour force composition (such as the matched employer-employee data used in this paper).

\section{REFERENCES}

Anxo, Dominique, Yusuf Kocoglu and Lannart Flood. 2002. "Offre de travail et répartition des activités domestiques et parentales au sein du couple: une comparaison entre la France et la Suède”, Economie et Statistique, Vol. 352, No. 3, pp. 127-148.

Aubert, Patrick, and Bruno Crépon. 2003. "La productivité des salariés âgés: une tentative d'estimation”, Economie et Statistique, Vol. 368, pp. 95-119.

Baltes, Boris. B., Thomas E. Briggs, Joseph W. Huff, Julie A. Wright, and George A. Neuman. 1999. "Flexible and Compressed Workweek Schedules: A Meta-analysis of Their Effects on Work-related Criteria”, Journal of Applied Psychology, Vol. 84, No. 4, pp. 496513.

Bardasi, Elena, and Janet C. Gornick. 2008. "Working for Less? Women's Part-Time Wage Penalties Across Countries”, Feminist Economics, Vol. 14, No. 1, pp. 37-72.

Barzel, Yoram. 1973. “The Determination of Daily Hours and Wages”, Quarterly Journal of Economics, Vol. 87, No. 2, pp. 220-238.

Black, Sandra, and Lisa Lynch. 2001. "How To Compete: The Impact of Workplace Practices and Information Technology on Productivity”, Review of Economics and Statistics, Vol. 83, No. 3, pp. 434-445.

Blau, Francine D.. 1984. “Discrimination Against Women: Theory and Evidence”. In William A. Darity, (Ed.), Labor Economics: Modern Views. Kluwer, Boston.

Bonamy, Joel, and May Nicola. 1997. "Service and Employment Relationship”, The Service Industries Journal, Vol. 17, No. 4, pp. 544-563.

Booth, Alison, and Margi Wood. 2008. "Back-to-front Down-under? Part-time/Full-time Wage Differentials in Australia”, Industrial Relations, Vol. 47, No. 1, pp. 114-135.

Branine, Mohamed. 1999. "Part-time Work in the Public Health Service of Denmark, France and the UK”, International Journal of Human Resource Management, Vol. 10, No. 3, pp. 411-429. 
Branine, Mohamed. 2003. Part-time Work and Job Sharing in Health Care: Is the NHS a Family-friendly Employer?”, Journal of Health Organization and Management, Vol. 17, No. 1, pp. 53-68.

Brewster, Chris, Ariane Hegewisch, and Lesley Mayne. 1994. “Flexible Working Practices: The Controversy and the Evidence”. In Brewster Chris, Hegewisch Ariane, (Eds), Policy and Practice in European Human Resource Management: The Price Waterhouse Cranfield Survey. Routledge, London.

Cataldi, Alessandra, Stephan Kampelmann, and François Rycx. 2012. "Does It Pay to Be Productive? The Case of Age Groups”, International Journal of Manpower, Vol. 33, No. 3, pp. 264-83.

Connolly, Sara, and Mary Gregory. 2008. "Moving Down: Women’s Part-Time Work And Occupational Change in Britain 1991-2001”, Economic Journal, No 118, pp. F52F76.Connolly, Sara, and Mary Gregory. 2010. "Dual Tracks: Part-time Work in Lifecycle Employment for British Women”, Journal of Population Economics, Vol. 23, No 3, pp. 907-931.

Daerden, Lorraine, Howard Reed and John Van Reenen. 2006. “The Impact of Training on Productivity and Wages: Evidence from British Panel Data”, Oxford Bulletin of Economics and Statistics, Vol. 68, No. 4, pp. 397-421.

Demunter, Christophe. 2000. "Structure and Distribution of Earnings Survey: Analysis 1995”, Statistics Belgium Working paper, Brussels.

Edwards, Christine, and Olive Robinson. 2000. "Managing Parttimers in the Police Service: A Study of Inflexibility”, Human Resource Management Journal, Vol. 9, No. 4, pp. 5-18.

Edwards, Christine, and Olive Robinson. 2004. "Evaluating the Business Case for Part-time Working amongst Qualified Nurses”, British Journal of Industrial Relations, Vol. 42, No. 1, pp. 167-183.

Felstead, Alan, David Ashton and Francis Green. 2000. “Are Britain’s Workplace Skills Becoming More Unequal?”, Cambridge Journal of Economics, Vol. 24, No. 6, pp. 709727.

Göbel, Christian, and Thomas Zwick. 2012. “Age and Productivity: Sector Differences”, De Economist, Vol. 160, No. 1, pp. 35-57.

Gottschalk, Peter. 1978. "A Comparison of Marginal Productivity and Earnings by Occupation”, Industrial and Labor Relations Review, Vol. 31, No. 3, pp. 368-378.

Grimshaw, Damian, and Jill Rubery. 2001. “The Gender Pay Gap. Research Review”. Equal Opportunities Commission, London. 
Hagemann, Helmut, Klaus Sommerfeld, Markus Dingier, Wolfgang Miiffer, Clans Neuberger, and Christel Delker. 1994. “Divide To Win: The Potential in Flexible Part-time Work”, McKinsey \& Company.

Hansen, Lars. 1982. "Large Sample Properties of Generalized Method of Moments Estimators”, Econometrica, Vol. 50, No. 4, pp. 1029-54.

Hardoy, Inés, and Pål Schøne. 2006. “The Part-time Wage Gap in Norway: How Large Is It Really?”, British Journal of Industrial Relations, Vol. 44, No. 2, pp. 263-82.

Hellerstein, Judith K., and David Neumark. 2004. "Production Function and Wage Equation Estimation with Heterogeneous Labor: Evidence from a New Matched Employeremployee Data Set”, NBER Working Paper no. 10365, Cambridge, MA.

Hellerstein, Judith K., David Neumark, and Kenneth R. Troske. 1999. “Wages, Productivity and Worker Characteristics: Evidence from Plant-level Production Functions and Wage Equations”, Journal of Labor Economics, Vol. 17, No. 2, pp. 409-46.Hirsch, Barry T. 2005. "Why Do Part-time Workers Earn Less? The Role of Worker and Job Skills", Industrial and Labor Relations Review, Vol. 58, No. 4, pp. 525-51.

Institute for the Equality of Women and Men. 2010. How to Close the Gender Pay Gap? Strategies and Good Practices of States and Social Partners in Europe”, Dépôt nr. D/2010/10.043/14, Brussels.

Jepsen, Maria. 2001. "Evaluation des différentiels salariaux en Belgique: hommes-femmes et temps partiel-temps plein”, Reflets et perspectives de la vie économique, Vol. XL, No. 1-2, pp. 51-63.

Jepsen, Maria, Sile O’Dorchai, Robert Plasman, and François Rycx. 2005. “The Wage Penalty Induced by Part-time Work: The Case of Belgium”, Brussels Economic Review, Vol. 48, No. 1-2, pp. 73-94.

Kampelmann, Stephan, and Fançois Rycx. 2012. “Are Occupations Paid What They Are Worth? An Econometric Study of Occupational Wage Inequality and Productivity”, De Economist, Vol. 160, No. 3, pp. 257-287.

Koskela, Erkki, and Ronnie Schöb. 1999. "Does the Composition of Wage and Payroll Taxes Matter Under Nash Bargaining?”, Economics Letters, Vol. 64, No. 3, pp. 343-49.

Lewis, Suzan. 2001. "Restructuring Workplace Cultures: The Ultimate Work-family Challenge?”, Women in Management Review, Vol. 16, No. 1, pp. 21-29.

Lewis, Suzan. 2003. "Flexible Working Arrangements: Implementation, Outcomes and Management”, International Review of Industrial and Organizational Psychology, Vol. 18, pp. 1-28. 
Manning, Alan, and Barbara Petrongolo. 2008. "The Part-time Pay Penalty for Women in Britain”, Economic Journal, Vol. 118, No. 526, F28-F51.

Meulders, Danièle, and Sile O'Dorchai. 2009. “Gender and Flexibility in Working Time in Belgium”, Working paper DULBEA, Research Report, Nº9-08.RR, March.

Montgomery, Mark. 1988. "Hours of Part-time and Full-time Workers at the Same Firm”, Industrial Relations, Vol. 27, No. 3, pp. 394-406.

Nelen, Annemarie, Andries de Grip and Didier Fouarge. 2011. "Is Part-time Employment Beneficial for Firm Productivity?”, Research Memoranda 002. Maastricht. ROA, Research Centre for Education and the Labour Market.

O’Dorchai, Sile, Robert Plasman and François Rycx. 2007. The Part-time Wage Penalty in European Countries: How Large Is It for Men?”, International Journal of Manpower, Vol. 28, No. 7, pp. 571-603.

OECD. 2009. Measuring Capital. OECD, Paris.

OECD. 2012. "Labour Market Statistics: Full-time Part-time Employment - Common Definition”, OECD Employment and Labour Market Statistics (database).

Perry-Smith, Jill E., and Terry C. Blum. 2000. "Work-family Human Resource Bundles and Perceived Organizational Performance”, Academy of Management Journal, Vol. 43, No. 6, pp. 1107-17.

Pierce, Jon L., and John W. Newstrom. 1983. "The Design of Flexible Work Schedules and Employee Responses: Relationships and Process”, Journal of Occupational Behavior, Vol. 4, No. 4, pp. 247-62.

Plasman, Dominique. 2007. “Femmes et temps partiel”, Brochure d'information, Femmes prévoyantes socialistes, Bruxelles.

Riley, Nicola-Maria. 1997. "Determinants of Union Membership: A Review”, Labour, Vol. 11, No. 2, pp. 265-301.

Rodgers, Joan R. 2004. "Hourly Wages of Full-time and Part-time Employees in Australia”, Australian Journal of Labour Economics, Vol. 7, No. 2, pp. 231-54.

Russo, Giovanni, and Wolter Hassink. 2008. “The Part-Time Wage Gap: A Career Perspective”, De Economist, Vol. 156, No. 2, pp. 145-74.

Shepard, Edward, Thomas Clifton, and Douglas Kruse. 1996. "Flexible Work Hours and Productivity: Some Evidence from the Pharmaceutical Industry”, Industrial Relations, Vol. 35, No. 1, pp. 123-39.

Skåtun, John D. 1998. "Divide the Hours and Conquer the Surplus: Part-time Workers and Pay”, Economics Letters, Vol. 61, No. 2, pp. 235-42. 
Stanworth, Celia M. 1999. “A Best Case Scenario? Non-manual Part-time Work and Jobsharing in UK Local Government in the 1990s”, Community, Work \& Family, Vol. 2, No. 3, pp. 295-310.

Teulings, Coen, and Joop Hartog. 1998. Corporatism or Competition? Labour Contracts, Institutions and Wage Structures in International Comparison. Cambridge University Press, Cambridge.

Vandenberghe, Vincent. 2011. "Firm-level Evidence on Gender Wage Discrimination in the Belgian Private Economy”, Labour, Vol. 25, No. 3, pp. 330-49.

Van Ours, Jan C., and Lenny Stoeldraijer. 2011. “Age, Wage and Productivity in Dutch Manufacturing”, De Economist, Vol. 159, No. 2, pp. 159-92.

Walby, Sylvia, and Wendy Olsen (2003), 'The UK Gender Wage Gap and Gendered Work Histories', Paper Presented to the conference of the British Household Panel Survey, Institute for Social and Economic Research, University of Essex. 
FIGURE 1 - REASONS FOR WORKING LESS THAN 30 HOURS PER WEEK

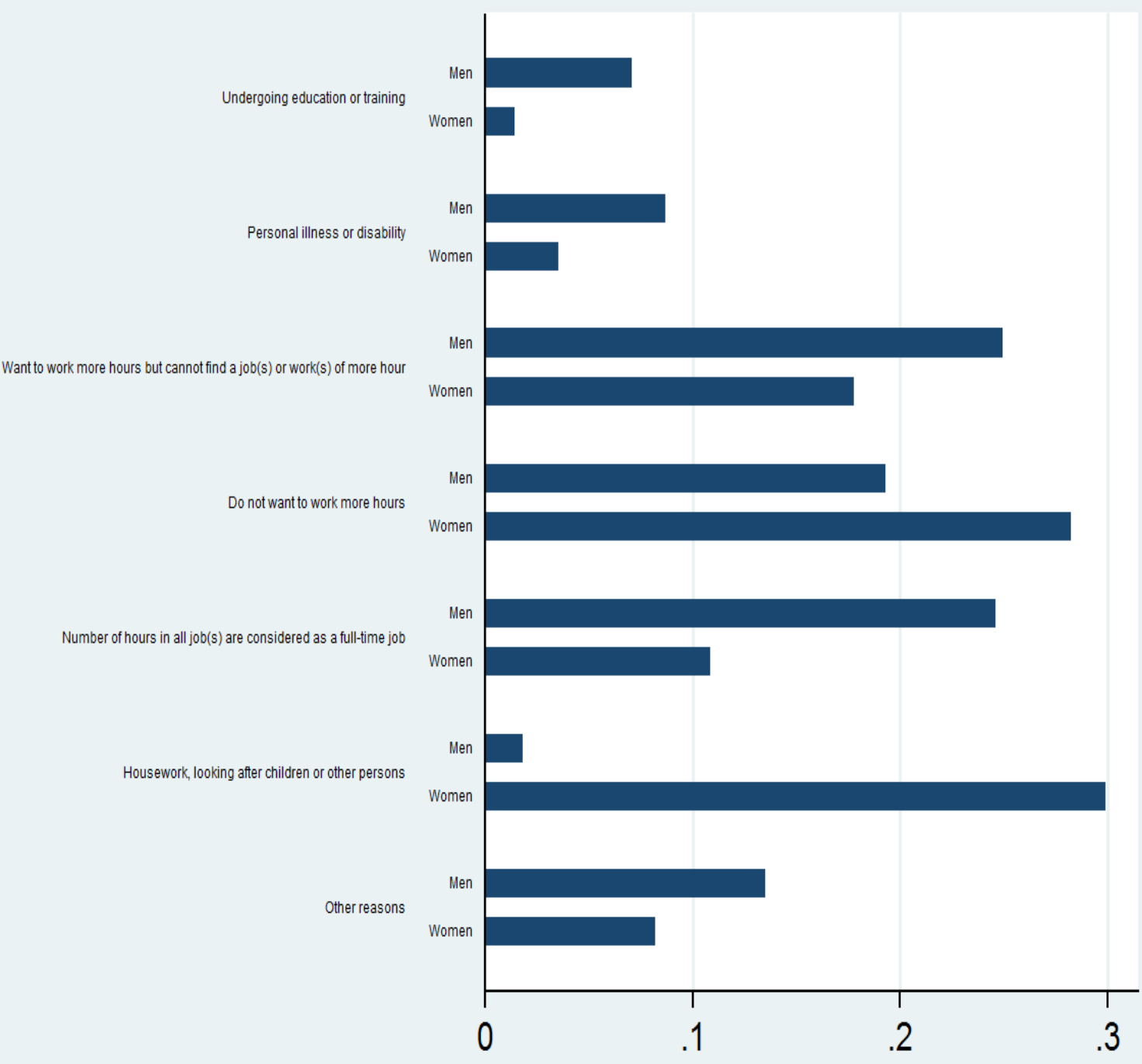

Source: Belgian sample of EU-SILC panel, 2008-2010. 
FIGURE 2 - DISTRIBUTION OF INDIVIDUALS ACCORDING TO WEEKLY WORKING HOURS (1999-2010)

a) Women

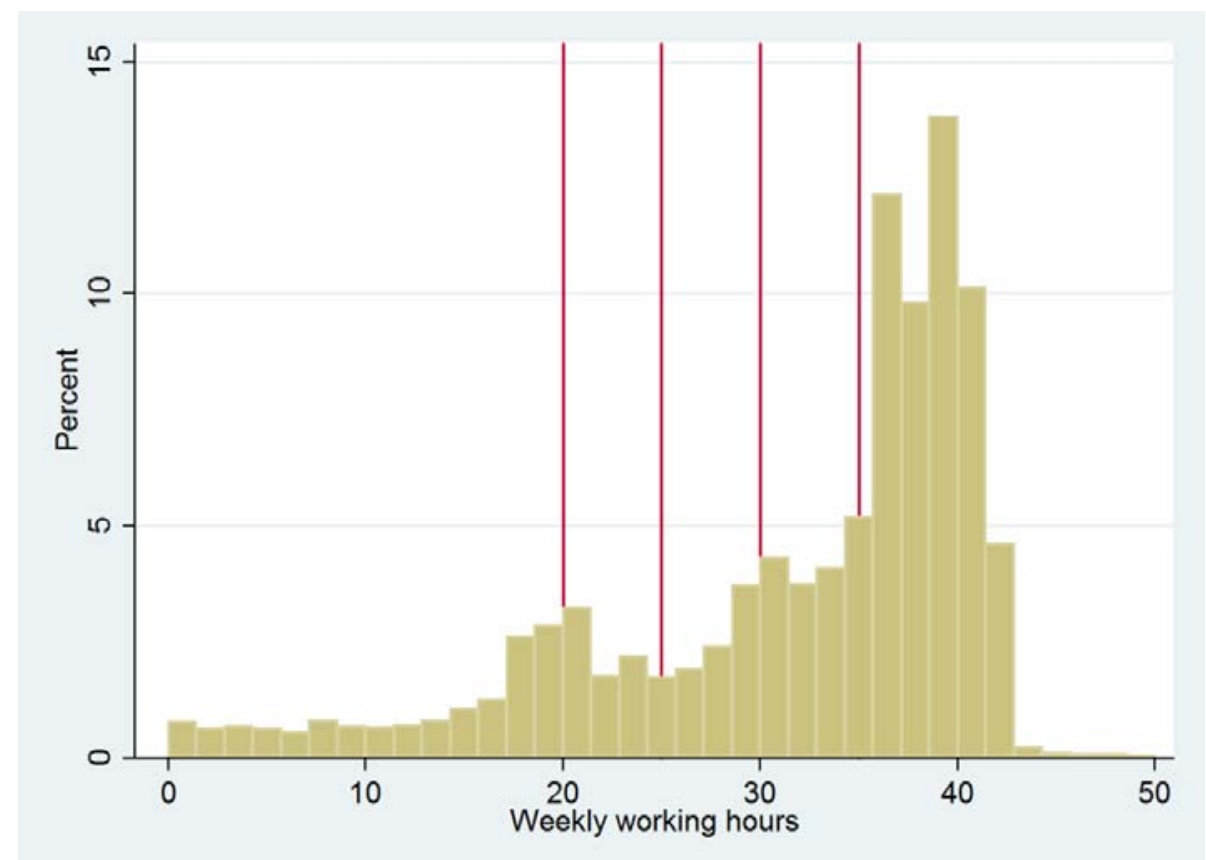

b) Men

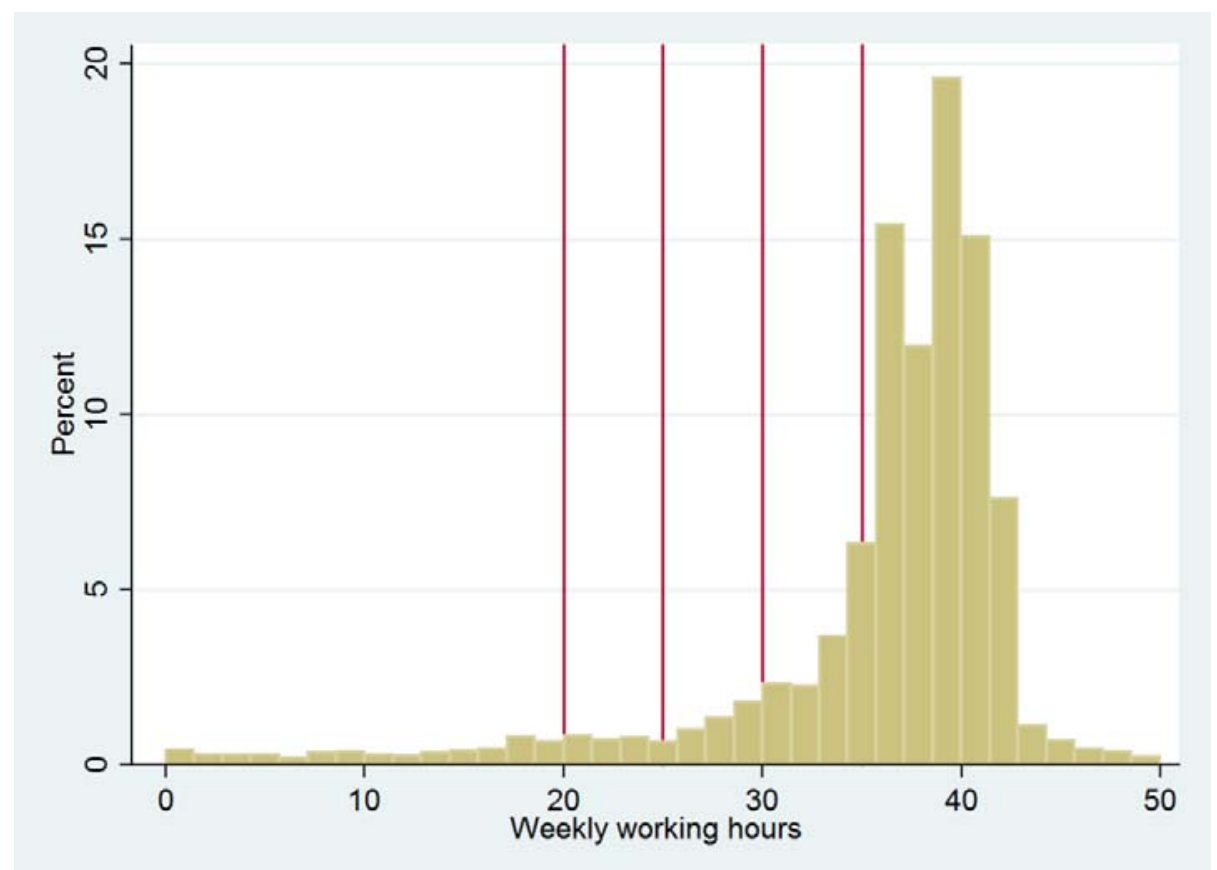

Notes : Data source: SES-SBS 1999-2010. Vertical lines represent 20, 25, 30 and 35 hours per week. 
TABLE 1 - AVERAGE GROSS HOURLY WAGES (1999-2010)

\begin{tabular}{l|ccc}
\hline & Men & Women & $\begin{array}{c}\text { (Wage men - wage women)/ } \\
\text { wage women }\end{array}$ \\
\hline Full-time (FT) & 16.57 euros & 14.98 euros & 0.11 \\
\hline Long part-time (LPT) & 14.79 euros & 13.79 euros & \\
(Wage FT-wage LPT) / & 0.12 & 0.09 & 0.20 \\
wage LPT & & & \\
\hline Short part-time (SPT) & 14.30 euros & 11.88 euros \\
$\begin{array}{l}\text { (Wage FT-wage SPT) / } \\
\text { wage SPT }\end{array}$ & 0.16 & 0.26 & \\
\hline $\begin{array}{l}\text { Notes: Constant 2004 euros deflated with CPI. } \\
\text { Short part-time: [0;25[ ; long part-time [ 25;35[. }\end{array}$
\end{tabular}


TABLE 2 - DESCRIPTIVE STATISTICS AT THE FIRM AND INDIVIDUAL LEVEL (MEAN VALUES FOR 1999-2010)

\begin{tabular}{|c|c|c|c|c|c|}
\hline \multirow[t]{2}{*}{ Variables: } & \multirow[t]{2}{*}{ Firm level } & \multicolumn{4}{|c|}{ Individual level } \\
\hline & & Total & Full-time $^{1}$ & $\begin{array}{l}\text { Long part- } \\
\text { time }^{2}\end{array}$ & $\begin{array}{l}\text { Short part- } \\
\text { time }^{3}\end{array}$ \\
\hline $\begin{array}{l}\text { Ln (added value per hour), constant } 2004 \\
\text { euros }\end{array}$ & 3.78 & 3.81 & 3.86 & 3.76 & 3.63 \\
\hline Ln (hourly wage), constant 2004 euros & 2.79 & 2.76 & 2.79 & 2.69 & 2.66 \\
\hline Pay hours per week & 1097.0 & 35.4 & 39.4 & 31.1 & 16.2 \\
\hline Full-time $(\%)^{1}$ & 76.8 & & & & \\
\hline Long part-time $(\%)^{2}$ & 17.6 & & & & \\
\hline Short part-time $(\%)^{3}$ & 5.5 & & & & \\
\hline Women (\%) & 22.0 & 22.4 & 18.5 & 27.6 & 38.9 \\
\hline Workers $<40$ years $(\%)$ & 52.1 & 51.6 & 53.3 & 48.5 & 45.3 \\
\hline Workers $>=40$ years $(\%)$ & 47.9 & 48.5 & 46.7 & 51.5 & 54.7 \\
\hline Education level 1 (ISCED 1 and 2) & 32.5 & 34.2 & 30.4 & 41.8 & 46.4 \\
\hline Education level 2 (ISCED 3 and 4) & 41.6 & 41.2 & 39.6 & 45.2 & 44.2 \\
\hline Education level 3 (ISCED 5, 6 and 7) & 25.9 & 24.6 & 30.1 & 13.0 & 9.5 \\
\hline Workers with fixed-term contracts (\%) & 3.8 & 4.5 & 4.0 & 4.3 & 8.2 \\
\hline Managers (\%) & 4.0 & 3.7 & 4.9 & 1.3 & 0.9 \\
\hline Professionals (\%) & 10.9 & 10.3 & 13.6 & 4.1 & 2.6 \\
\hline Technicians and ass. professionals (\%) & 8.2 & 7.9 & 9.8 & 4.5 & 3.0 \\
\hline Clerical occupations (\%) & 14.9 & 14.6 & 16.3 & 12.7 & 12.4 \\
\hline Craft (\%) & 25.4 & 25.3 & 23.4 & 31.8 & 27.6 \\
\hline Machine operators (\%) & 25.5 & 26.7 & 22.7 & 32.6 & 29.2 \\
\hline Service (\%) & 2.6 & 2.7 & 2.3 & 1.7 & 5.8 \\
\hline Elementary occupations (\%) & 8.5 & 8.9 & 6.9 & 11.3 & 18.5 \\
\hline Firm size (number of workers) & 459.7 & 749.2 & 739.8 & 799.4 & 717.8 \\
\hline Mining and quarrying (\%) & 0.00 & 0.4 & 0.4 & 0.3 & 0.2 \\
\hline Manufacturing (\%) & 62.3 & 63.5 & 62.7 & 69.4 & 58.2 \\
\hline Electricity, gas and water supply (\%) & 0.00 & 0.1 & 0.1 & 0.0 & 0.0 \\
\hline Construction (\%) & 13.2 & 10.9 & 11.8 & 8.6 & 9.3 \\
\hline Wholesale and retail trade (\%) & 7.2 & 7.0 & 7.0 & 7.4 & 5.8 \\
\hline Hotels and restaurants (\%) & 1.3 & 1.0 & 1.0 & 0.8 & 2.1 \\
\hline Transport, storage and communication & 6.1 & 8.0 & 7.6 & 7.7 & 11.7 \\
\hline Financial intermediation (\%) & 1.1 & 0.8 & 0.9 & 0.8 & 0.6 \\
\hline Real estate, renting and business & 8.3 & 8.3 & 8.7 & 5.0 & 12.1 \\
\hline Number of individual observations & & 128,006 & 89,875 & 25,066 & 13.065 \\
\hline Distribution in \% & & 100 & 70.2 & 19.6 & 10.2 \\
\hline Number of firm-year-observations & 5,171 & & & & \\
\hline
\end{tabular}

Notes: ${ }^{1}$ Full-time: $>=35$ work hours per week. ${ }^{2}$ Long part-time: $>=25 \&<35$ work hours per week. ${ }^{3}$ Short part-time: $<25$ work hours per week. 
TABLE 3 - DIFFERENCE GMM ESTIMATES, BASELINE SPECIFICATION

(MODEL 1)

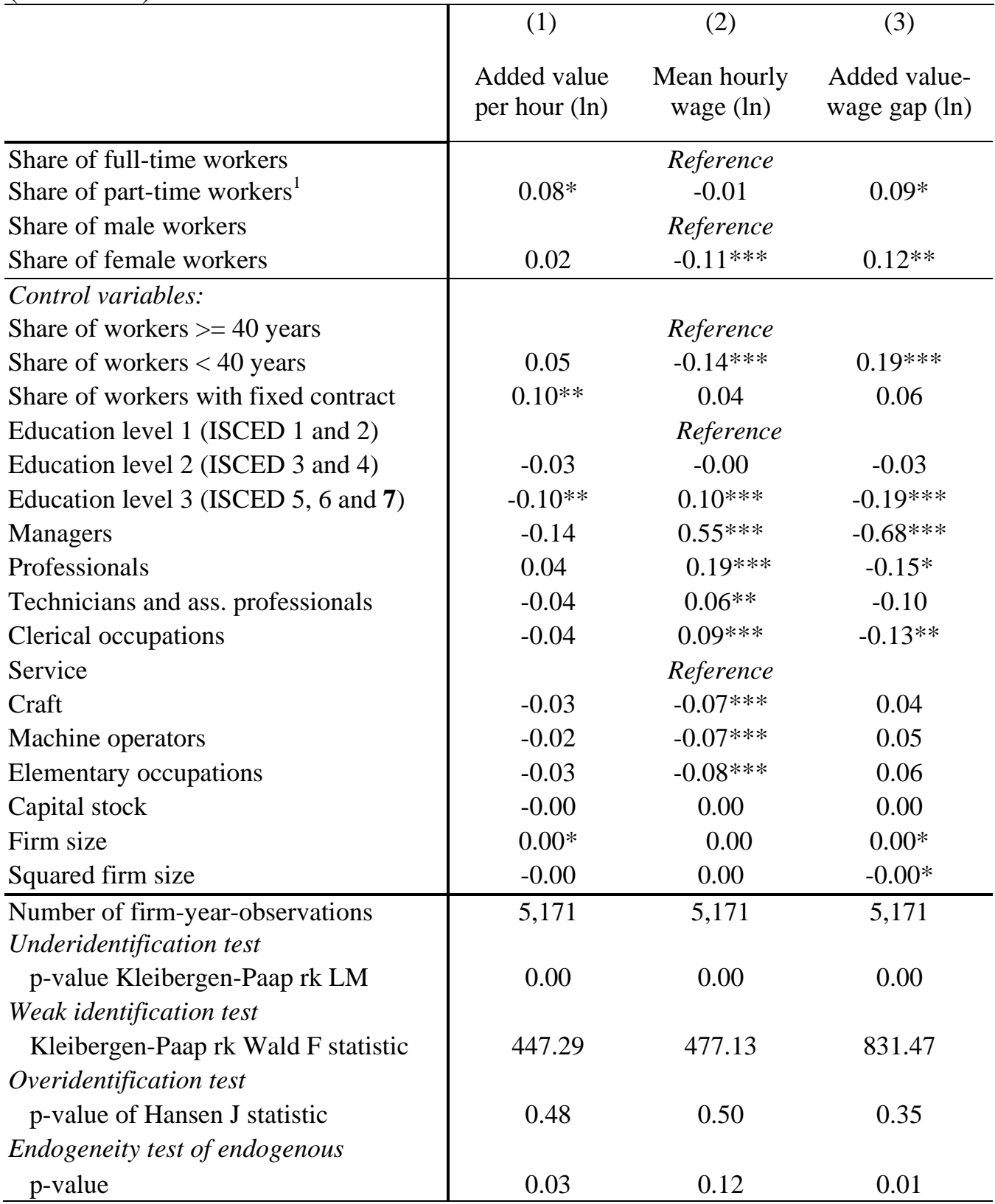

Notes: $* * * / * * / *$ significant at the 1,5 and $10 \%$ level. All models include year dummies and control for the firm's sector of activity at NACE 1 . Part-time $<35$ hours per week. First two lags of main explanatory variables are used as instruments. 
TABLE 4 -DIFFERENCE GMM ESTIMATES, DISTINGUISHING SHORT AND LONG PART-TIME (MODEL 2 )

\begin{tabular}{|c|c|c|c|c|c|c|c|c|c|}
\hline & $\begin{array}{l}\text { Part-time } \\
\text { (1) } \\
\text { Added value } \\
\text { per hour (ln) }\end{array}$ & $\begin{array}{l}\text { Model } 2.1 \\
\text { hresholds: } 0-20 \\
\quad(2) \\
\text { Mean hourly } \\
\text { wage (ln) }\end{array}$ & $\begin{array}{l}\text { 20-35/35 } \\
\quad \text { (3) } \\
\text { Added value- } \\
\text { wage gap (ln) }\end{array}$ & $\begin{array}{l}\text { Part-tim } \\
\text { (4) } \\
\text { Added value } \\
\text { per hour (ln) }\end{array}$ & $\begin{array}{l}\text { Model } 2.2 \\
\text { hresholds: } 0-25 \\
\quad(5) \\
\text { Mean hourly } \\
\text { wage (ln) }\end{array}$ & $\begin{array}{l}\text {-35/35 } \\
\quad(6) \\
\text { Added value- } \\
\text { wage gap (ln) }\end{array}$ & $\begin{array}{l}\text { Part-tim } \\
\qquad(7) \\
\text { Added value } \\
\text { per hour (ln) }\end{array}$ & $\begin{array}{l}\text { Model 2.3 } \\
\text { thresholds: } 0-3 \\
\quad(8) \\
\text { Mean hourly } \\
\text { wage (ln) }\end{array}$ & $\begin{array}{l}\text { 30-35/35 } \\
\text { (9) } \\
\text { Added value- } \\
\text { wage gap (ln) }\end{array}$ \\
\hline $\begin{array}{l}\text { Share of full-time workers } \\
\text { Share of short part-time workers }{ }^{1} \\
\text { Share of long part-time workers } \\
\text { Share of male workers } \\
\text { Share of female workers }\end{array}$ & $\begin{array}{l}-0.21 \\
0.11^{* *} \\
0.02\end{array}$ & $\begin{array}{l}\text { Reference } \\
\quad 0.04 \\
0.01 \\
\text { Reference } \\
-0.11^{* * *}\end{array}$ & $\begin{array}{l}-0.20 \\
0.11^{* *} \\
0.13^{* *}\end{array}$ & $\begin{array}{l}-0.10 \\
0.12^{* *} \\
0.03\end{array}$ & $\begin{array}{l}\text { Reference } \\
\quad 0.03 \\
0.00 \\
\text { Reference } \\
-0.11^{* * *}\end{array}$ & $\begin{array}{c}-0.11 \\
0.12 * * \\
0.13^{* * *}\end{array}$ & $\begin{array}{c}0.09 \\
0.08^{*} \\
0.01\end{array}$ & $\begin{array}{l}\text { Reference } \\
\quad-0.02 \\
0.02 \\
\text { Reference } \\
-0.11^{* * *}\end{array}$ & $\begin{array}{l}0.12 \\
0.07\end{array}$ \\
\hline \multicolumn{10}{|l|}{ Control variables: } \\
\hline $\begin{array}{l}\text { Share of workers }>=40 \text { years } \\
\text { Share of workers }<40 \text { years } \\
\text { Share of workers with fixed contract } \\
\text { Education level } 1 \text { (ISCED } 1 \text { and } 2 \text { ) }\end{array}$ & $\begin{array}{c}0.04 \\
0.09 *\end{array}$ & $\begin{array}{l}\text { Reference } \\
-0.14^{* * *} \\
0.06^{* *} \\
\text { Reference }\end{array}$ & $\begin{array}{c}0.19 * * * \\
0.06\end{array}$ & $\begin{array}{c}0.05 \\
0.10^{*}\end{array}$ & $\begin{array}{c}\text { Reference } \\
-0.14^{* * *} \\
0.06^{* *} \\
\text { Reference }\end{array}$ & $\begin{array}{c}0.19 * * * \\
0.06\end{array}$ & $\begin{array}{c}0.05 \\
0.10^{*}\end{array}$ & $\begin{array}{c}\text { Reference } \\
-0.14^{* * *} \\
0.05^{*} \\
\text { Reference }\end{array}$ & $\begin{array}{c}0.19 * * * \\
0.06)\end{array}$ \\
\hline Education level 2 (ISCED 3 and 4) & -0.03 & 0.00 & $-0.03(0.04)$ & -0.03 & 0.00 & -0.03 & $-0.03-0.0304$ & -0.00 & -0.03 \\
\hline Education level 3 (ISCED 5, 6 and 7) & $-0.10 * *$ & $0.10^{* * *}$ & $-0.20 * * *$ & $-0.10^{* *}$ & $0.10^{* * *}$ & $-0.19 * * *$ & $-0.09 * *$ & $0.10^{* * *}$ & $-0.19 * * *$ \\
\hline Managers & -0.14 & $0.52 * * *$ & $-0.68 * * *$ & -0.14 & $0.52 * * *$ & $-0.68 * * *$ & -0.14 & $0.53 * * *$ & $-0.68 * * *$ \\
\hline Professionals & 0.03 & $0.18^{* * *}$ & $-0.14^{*}$ & 0.03 & $0.18^{* * *}$ & $-0.14^{*}$ & 0.03 & $0.18^{* * *}$ & $0.15^{*}$ \\
\hline Technicians and ass. professionals & -0.04 & $0.04 *$ & -0.09 & -0.05 & $0.04 *$ & -0.10 & -0.04 & $0.05 *$ & -0.09 \\
\hline $\begin{array}{l}\text { Clerical occupations } \\
\text { Service }\end{array}$ & -0.05 & $\begin{array}{l}0.08^{* * *} \\
\text { Reference }\end{array}$ & $-0.14 * *$ & \multicolumn{3}{|c|}{ Reference } & \multicolumn{3}{|c|}{ Reference } \\
\hline Craft & -0.04 & $-0.08 * * *$ & 0.03 & -0.04 & $-0.08 * * *$ & 0.03 & -0.03 & $-0.08 * * *$ & 0.05 \\
\hline Machine operators & -0.03 & $-0.09 * * *$ & 0.04 & -0.03 & $-0.08^{* * *}$ & 0.04 & -0.02 & $-0.08^{* * *}$ & 0.04 \\
\hline Elementary occupations & -0.03 & $-0.09 * * *$ & 0.04 & -0.04 & $-0.09 * * *$ & 0.04 & -0.02 & $-0.09 * * *$ & 0.06 \\
\hline Capital & 0.00 & 0.00 & 0.00 & 0.00 & -0.00 & 0.00 & 0.00 & -0.00 & 0.00 \\
\hline Firm size & $0.00 *$ & 0.00 & $0.00 *$ & $0.00 *$ & 0.00 & $0.00 *$ & $0.00 *$ & 0.00 & $0.00 *$ \\
\hline Squared firm size & $-0.00 *$ & 0.00 & $-0.00 *$ & -0.00 & 0.00 & $-0.00 *$ & -0.00 & 0.00 & $-0.00 *$ \\
\hline $\begin{array}{l}\text { Number of firm-year-observations } \\
\text { Underidentification test }\end{array}$ & 5,171 & 5,171 & 5,171 & 5,171 & 5,171 & 5,171 & 5,171 & 5,171 & 5,171 \\
\hline $\begin{array}{l}\text { p-value Kleibergen-Paap rk LM } \\
\text { Weak identification test }\end{array}$ & 0.00 & 0.00 & 0.00 & 0.00 & 0.00 & 0.00 & 0.00 & 0.00 & 0.00 \\
\hline $\begin{array}{l}\text { Kleibergen-Paap rk Wald F statistic } \\
\text { Overidentification test }\end{array}$ & 42.47 & 42.47 & 42.47 & 63.38 & 63.38 & 63.38 & 119.09 & 119.09 & 119.09 \\
\hline $\begin{array}{l}\text { p-value of Hansen J statistic } \\
\text { Endogeneity test }\end{array}$ & 0.70 & 0.05 & 0.58 & 0.72 & 0.08 & 0.49 & 0.52 & 0.21 & 0.65 \\
\hline p-value & 0.03 & 0.73 & 0.04 & 0.03 & 0.49 & 0.04 & 0.07 & 0.18 & 0.03 \\
\hline
\end{tabular}

Notes: ***/**/* significant at the 1, 5 and 10\% level. All models include year dummies and control for the firm's sector of activity at NACE 1. First two lags of main explanatory variables are used as instruments. 
TABLE 5 -DIFFERENCE GMM ESTIMATES, DISTINGUISHING SHORT AND LONG PART-TIME WITH GENDER INTERACTION (MODEL 3)

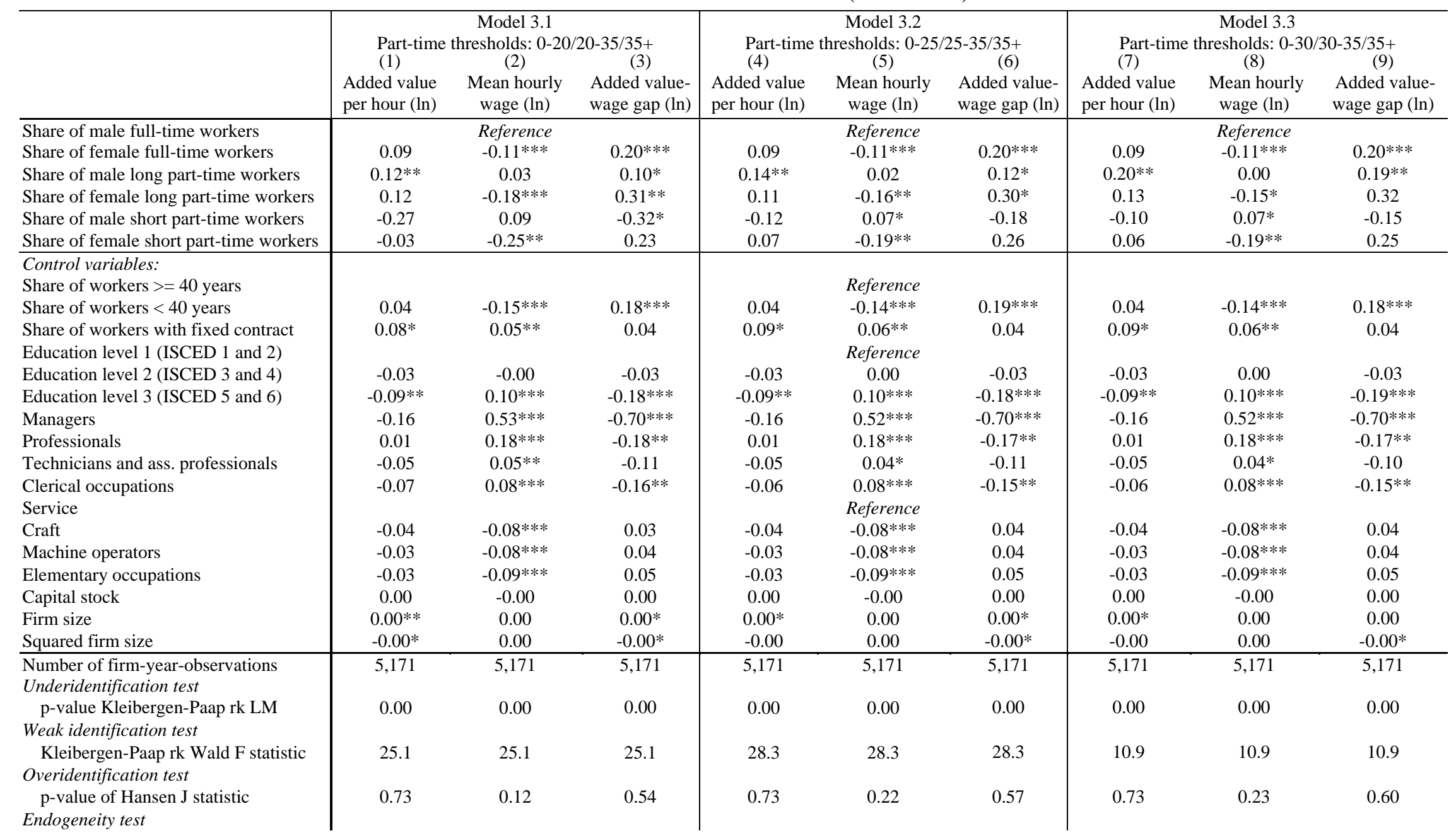


p-value

0.09

0.77

\begin{tabular}{l|l}
0.06 & 0.08
\end{tabular}

0.78

0.08

0.07

0.88

0.04

Notes: $* * * / * * * *$ significant at the 1,5 and $10 \%$ level. All models include year dummies and control for the firm's sector of activity at NACE 1 . First two lags of main explanatory variables are used as instruments. 


\section{APPENDIX A - ADDITIONAL DESCRIPTIVE STATISTICS AT THE INDIVIDUAL LEVEL (1999-2010)}

\begin{tabular}{|c|c|c|c|c|c|c|}
\hline & \multicolumn{3}{|c|}{ Male workers } & \multicolumn{3}{|c|}{ Female workers } \\
\hline & Full-time $^{1}$ & $\begin{array}{l}\text { Long } \\
\text { part-time }{ }^{2}\end{array}$ & $\begin{array}{l}\text { Short } \\
\text { part-time }\end{array}$ & Full-time $^{1}$ & $\begin{array}{l}\text { Long } \\
\text { part-time }{ }^{2}\end{array}$ & $\begin{array}{l}\text { Short } \\
\text { part-time }^{3}\end{array}$ \\
\hline \multicolumn{7}{|l|}{ Occupations (\%): } \\
\hline Managers & 5.2 & 1.2 & 1.3 & 3.6 & 1.7 & 0.4 \\
\hline Professionals & 13.4 & 3.1 & 2.5 & 14.4 & 6.7 & 2.9 \\
\hline $\begin{array}{l}\text { Technicians and ass. } \\
\text { professionals }\end{array}$ & 9.8 & 3.6 & 3.0 & 9.9 & 6.6 & 2.9 \\
\hline Clerical occupations & 10.6 & 4.4 & 4.4 & 40.1 & 32.9 & 24.4 \\
\hline Craft & 27.0 & 38.6 & 35.2 & 8.6 & 15.3 & 16.3 \\
\hline Machine operators & 25.0 & 37.8 & 35.1 & 13.0 & 20.0 & 20.4 \\
\hline Service & 2.2 & 1.3 & 3.5 & 3.2 & 2.5 & 9.1 \\
\hline $\begin{array}{l}\text { Elementary } \\
\text { occupations }\end{array}$ & 6.8 & 10.1 & 15.1 & 7.3 & 14.3 & 23.5 \\
\hline \multicolumn{7}{|l|}{ Sectors (\%): } \\
\hline Mining and quarrying & 0.5 & 0.4 & 0.3 & 0.1 & 0.1 & 0.1 \\
\hline Manufacturing & 65.0 & 73.2 & 61.5 & 52.4 & 59.5 & 53.0 \\
\hline $\begin{array}{l}\text { Electricity, gas and } \\
\text { water supply }\end{array}$ & 0.1 & 0.0 & 0.0 & 0.1 & 0.0 & 0.0 \\
\hline Construction & 13.4 & 10.7 & 13.3 & 4.5 & 3.1 & 3.1 \\
\hline $\begin{array}{l}\text { Wholesale and retail } \\
\text { trade }\end{array}$ & 5.9 & 5.5 & 4.1 & 11.6 & 2.3 & 8.5 \\
\hline Hotels and restaurants & 0.8 & 0.6 & 1.8 & 1.9 & 1.2 & 2.6 \\
\hline $\begin{array}{l}\text { Transport, storage and } \\
\text { communication }\end{array}$ & 6.6 & 7.1 & 13.1 & 11.9 & 9.5 & 9.4 \\
\hline $\begin{array}{l}\text { Financial } \\
\text { intermediation }\end{array}$ & 0.6 & 0.2 & 0.2 & 2.2 & 2.4 & 1.2 \\
\hline $\begin{array}{l}\text { Real estate, renting } \\
\text { and business }\end{array}$ & 7.1 & 2.4 & 5.8 & 15.4 & 11.8 & 22.2 \\
\hline $\begin{array}{l}\text { Number of observations } \\
\text { (\% among respectively } \\
\text { male/female workers): }\end{array}$ & $\begin{array}{l}73,208 \\
(73.7)\end{array}$ & $\begin{array}{l}18,178 \\
(18.3)\end{array}$ & $\begin{array}{r}7,947 \\
(8.0)\end{array}$ & $\begin{array}{l}16,659 \\
(58.1)\end{array}$ & $\begin{array}{r}6,939 \\
(24.2)\end{array}$ & $\begin{array}{r}5,075 \\
(17.7)\end{array}$ \\
\hline
\end{tabular}

Notes: ${ }^{1}$ Full-time: $>=35$ work hours per week. ${ }^{2}$ Long part-time: $>=25 \&<35$ work hours per week. ${ }^{3}$ Short part-time: $<25$ work hours per week. 